OPEN ACCESS

Edited by:

Mudasir Ahmad,

University of Kashmir, India

Reviewed by:

Johannes Delgado-Ospina,

University of San Buenaventura

Cali, Colombia

Romee Jan,

Sant Longowal Institute of Engineering and Technology, India

*Correspondence:

Syeda Mahvish Zahra syedamahvish99@gmail.com; mahvish.zahra@aiou.edu.pk

Salam A. Ibrahim ibrah001@ncat.edu Shahida Anusha Siddiqui s.siddiqui@dil-ev.de

Specialty section: This article was submitted to Nutrition and Food Science Technology,

a section of the journal

Frontiers in Nutrition

Received: 16 September 2021 Accepted: 29 November 2021

Published: 20 January 2022

Citation:

Ranjha MMAN, Shafique $B$, Rehman A, Mehmood A, Ali A, Zahra SM, Roobab U, Singh A, Ibrahim SA and Siddiqui SA (2022)

Biocompatible Nanomaterials in Food

Science, Technology, and Nutrient Drug Delivery: Recent Developments and Applications.

Front. Nutr. 8:778155.

doi: 10.3389/fnut.2021.778155

\section{Biocompatible Nanomaterials in Food Science, Technology, and Nutrient Drug Delivery: Recent Developments and Applications}

\author{
Muhammad Modassar Ali Nawaz Ranjha ${ }^{1}$, Bakhtawar Shafique ${ }^{1}$, Abdur Rehman ${ }^{2}$, \\ Arshad Mehmood ${ }^{3}$, Ahmad Ali ${ }^{2}$, Syeda Mahvish Zahra ${ }^{1,4 *}$, Ume Roobab ${ }^{5}$, Ajay Singh ${ }^{6}$, \\ Salam A. Ibrahim $^{7 *}$ and Shahida Anusha Siddiqui ${ }^{8,9 *}$ \\ ${ }^{1}$ Institute of Food Science and Nutrition, University of Sargodha, Sargodha, Pakistan, ${ }^{2}$ State Key Laboratory of Food \\ Science and Technology, School of Food Science and Technology, Jiangnan University, Wuxi, China, ${ }^{3}$ Beijing Advance \\ Innovation Center for Food Nutrition and Human Health, School of Food and Health, Beijing Technology and Business \\ University, Beijing, China, ${ }^{4}$ Department of Environmental Design, Health and Nutritional Sciences, Allama Iqbal Open \\ University, Islamabad, Pakistan, ${ }^{5}$ School of Food Science and Engineering, South China University of Technology, \\ Guangzhou, China, ${ }^{6}$ Department of Food Technology, Mata Gujri College, Fatehgarh Sahib, India, ${ }^{7}$ Food Microbiology and \\ Biotechnology Laboratory, North Carolina Agricultural and Technical State University, Greensboro, NC, United States, \\ ${ }^{8}$ Technical University of Munich, Campus Straubing for Biotechnology and Sustainability, Straubing, Germany, ${ }^{9}$ German \\ Institute of Food Technologies (DIL e.V.), (Deutsches Institut für Lebensmitteltechnik (English version: German Institute of \\ Food Technologies)), Quakenbrück, Germany
}

Nanomaterials exist as potential biocompatible materials in nature and are being synthesized to provide extraordinary characteristics in various food industry sectors. Synthesis of biocompatible nanomaterials requires modification in the shape, density, and size of nanomaterials. Biocompatible nanomaterials are synthesized to reduce toxicity, decrease adverse effects in the gastrointestinal tract, and enhance immune response. Nanomaterials can target organs and tissues. Nanomaterials are found to be effectively compatible by interacting with functional foods and nutraceuticals. Applications of these nanomaterials are novel strategies in food industries such as food safety, food processing, food quality, food packaging, and food labeling. Various functions like detection of toxins and pathogens; production of biocompatible packaging; enhancement in color, flavor, and aroma; processing edible film, and sensing authenticity of food product are being accomplished with no toxicity. This review provides a systematic study on the biocompatibility of nanomaterials. It highlights the synthesis of biocompatible nanomaterials and advanced functions of these nanomaterials in the production area, processing industry, safety improvement, quality control, edible packaging films, biocompatibility, current developments, legislations and regulations for Nano-products, health and safety concerns, toxicity and public perceptions for use of nanomaterials.

Keywords: nanomaterials biocompatibility, food industry, food processing, food safety, food packaging, food labeling, nutrient drug delivery 


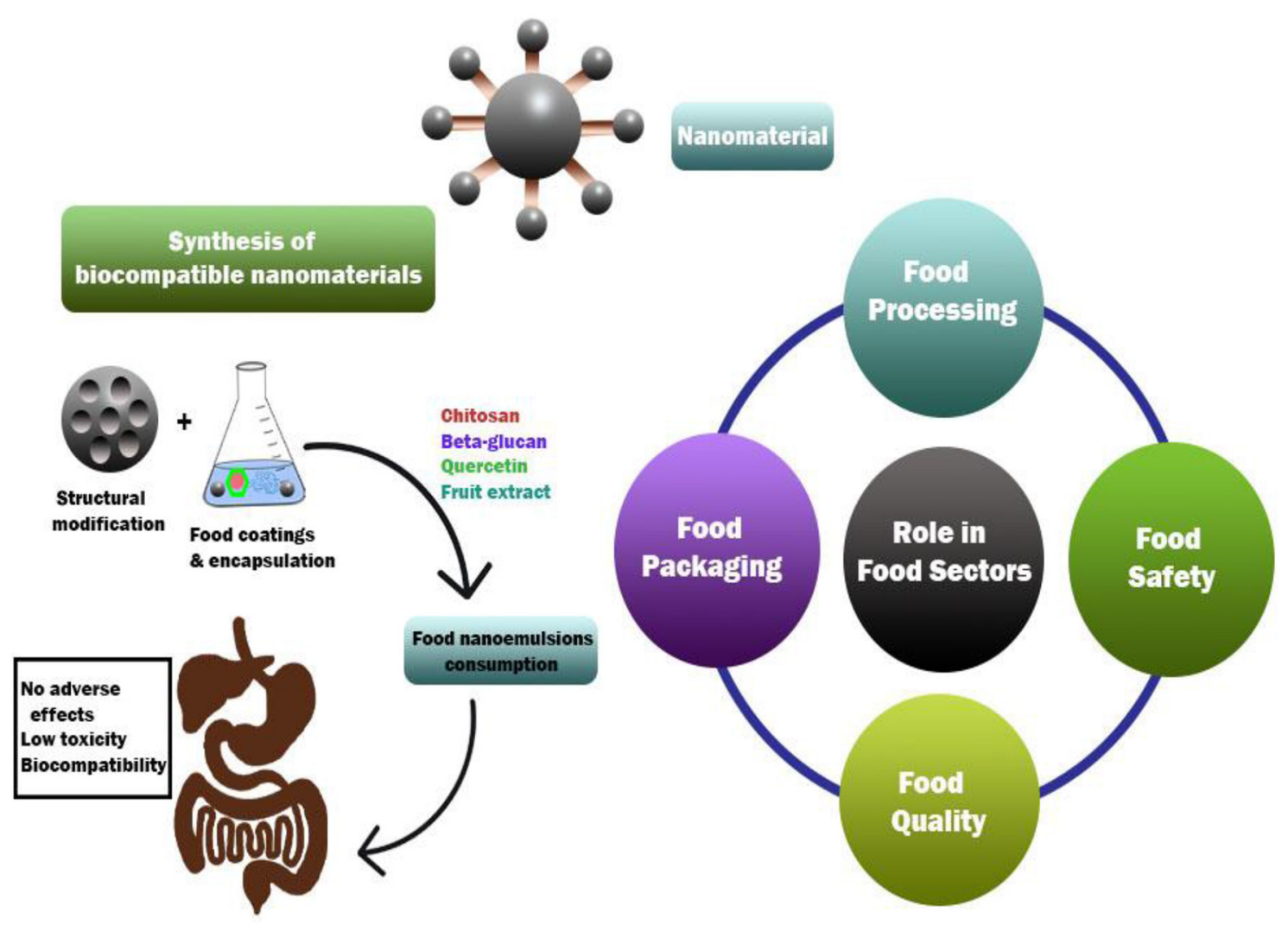

GRAPHICAL ABSTRACT | Graphical abstract of functions of biocompatible nanomaterials in food industry.

\section{INTRODUCTION}

Innovation has always been the priority of human beings (13). Biocompatible nanomaterials are applied to food technology according to their properties and goals achieved. Nanomaterials have specific potentials like surface effect, quantum size effect, small size effect, and quantum tunneling effect based on physicochemical properties. These properties affect their behavior in biosystems, for they may either be tolerated or disturb biochemical and/or physiological homeostasis (4). The capability of nanomaterials to reach target tissues or organs in the organism is much more significant than their counterparts. Biocompatible nanomaterials are recognized as foreign stimuli which enhance the levels of the immune response. Naturally-occurring $\beta$ glucans has immunomodulatory property and antitumor activity. Shape, size, and surface physicochemical characteristics affect nanoparticle distribution and pharmacokinetics in the human body (5).

Nanomaterials are those materials having particles with at least one external dimension being $100 \mathrm{~nm}$ or with an internal structure measuring $100 \mathrm{~nm}$. Nanomaterials are excellent absorbents with large surface areas despite being ultra-small, $\sim 1-$ $100 \mathrm{~nm}$ (6). Nanomaterials have diverse classifications depending on size, morphology, physical, and chemical properties. The properties of nanomaterials depend on the small grain size as they usually are pretty expressive. In the food sector, nanoparticles of zinc oxide, titanium dioxide, silica, and silver have been increasingly applied $(7,8)$. More novel applications of these nanoparticles are being addressed in the present era $(9,10)$. Nano-immune interactions should be paid special attention as immune cells recognize and engulf the particles (11).

Production of good quality food and safe evaluation by improved food sensing and good nanostructured ingredients is the aim of food processing (12-17). Silver, zinc, and calcium NPs have antimicrobial activity and biocompatibility, that's why are used as edible film (18). Generally, in food packaging and processing, nanomaterials are incorporated with polymers. The flexibility and durability of food contents get improved using these nanomaterials. The nanomaterials, along with food, enter the body by human consumption. Studying the toxicity mechanism of nanomaterials helps provide information regarding biocompatible nanomaterials (19).

Nanomaterials such as gold, nanoclays, titanium oxid, and silver are applicable in the food technology to achieve various goals like enhanced flavor, taste, appearance, shelf-life, dislikes, and likes of the consumers concerning health promising properties (20). Nanomaterials' properties could regulate physiological homeostasis and biochemical functionality. Antimicrobial properties of silver, calcium, and 
zinc nanoparticles are established as they are biocompatible and can be used as an edible film in food packaging (21).

Nanotechnology is being used in the production of innovative products with brand new properties. Nanomaterials of organic nature are called cellulosic nanomaterials (CNMs). CNMs are green in color, and it is possible to extract them from renewable sources, for example, wood pulp, tunicates, algae, and bacteria (22). Nanomaterials, such as metal nanoparticles, carbon nanotubes, nanostructured materials, nano-composite, and nanowires, have enhanced the biosensing and sensing design systems for applications in food analysis. Additionally, these nano biosystems are also carrying benefits in the design of novel strategies for food detection. Nanomaterials have various functions in the detection of foodborne pathogens to ensure food safety (23).

Recently, rapid progress has been made to develop the synthesized nanomaterials, although it has urged their concern of safety worldwide. In World Health Organization and Food and Agriculture Organization experts meeting in United Nations, the incredible nanomaterials' benefits in the food sectors are recognized. Nevertheless, the suggestion is given to developing the taxonomy to assist with risk management, and international and clear definitions should be revised for the nanomaterials' application (24). This review discusses the incorporation of nanomaterials into the matrices of polymers and biopolymers/natural hydrochlorides for preservation, quality, and safety purposes desirable in food science as per biocompatibility and functionalization.

\section{NANOMATERIALS IN DIFFERENT SECTORS OF FOOD INDUSTRY}

Nanotechnology is known as multi-purpose technology that can demonstrate its application in several scientific areas at the nanoscale. Nano-technology has a wide range in providing advantages and signifies a megatrend. Scientifically, its definition is the restructuring or control of matter at the molecular and atomic levels, whose size ranges from about $1-100 \mathrm{~nm}$. Advanced chemical and physical properties of nanomaterials are usually determined to provide applications that benefit society (25). Nanotechnology applications to the food and agricultural industry were first explained by the road map of the Department of Agriculture in the US in September 2003 (26).

European Nanotechnology Gateway has defined nano foods as the food in which nanotechnology techniques with nanoparticles are majorly used in harvesting, processing, and preserving food (27). The novel applications, materials, and products are expected to provide numerous improvements and advancements to the food and linked sectors, enhancing agriculture and distribution, storage, nano additives, food processing, safety, quality, and sensors to detect toxins and contaminants and innovative products' development (28).

Nano food packaging enhances the physicochemical qualities of food by reducing microbial load by acting on cell membranes and generation of reactive oxygen species and also provide physical, chemical, and mechanical resistance.
Contaminants in food matrices can be isolated and preconcentrated efficiently with the help of these nanoparticles. Furthermore, novel applications of nanomaterials include improvement in colors and flavors; detection and control of microbes, allergens, and contaminants; properties and performance of food packaging (29).

Nanomaterials are recognized for applying their technologies in food, food supplements, additives, and materials in contact with food. Internet databases' inventory reported that about 140 food products and food relevant sectors are acknowledged to claim the availability of nanomaterials in food. Application of nanomaterials has excellent diversity, containing bioactive ingredients that range from metal oxides, inorganic metal to organic nanomaterials (29). Nano-encapsulated resveratrol exhibited better anti-oxidant, anti-diabetic and anti-obesity potential than free resveratrol in the in vitro-digestion study, which emphasized further studies to be conducted for checking bioavailability and safety (30). The demand for the provision of healthy food is increasing day by day. Much attention should be paid to modernizing technologies of food processing to produce functional and novel food products containing enhanced benefits for health. Nano-technology has been applied to the industry of food in this context. It is widely studied to increase the biological efficacy and physicochemical stability of naturally occurring or fortified bioactive compounds during food processing (31).

\section{BIOCOMPATIBILITY OF NANOMATERIALS}

The biocompatibility of nanomaterials is the potential term that is attributed to significant safety concerns. Recently, scientists from the biological, medical, environmental, and chemical fields have drawn considerable attention to controlling and investigating the adverse impacts of nanomaterials. Several novel techniques (e.g., biomaterials gained from nature, biosynthesis, and chemical chain modification) are used to control nanotoxicity. These are also adopted to synthesize biocompatible nanomaterials with numerous sizes, functions, and shapes (e.g., quantum dots nanocrystals, nanotubes, nanowires, and nanoporous) $(32,33)$.

The negative impacts of nanomaterials are reduced by surface modifications, which require regulation in translocation, stability, density, and surface charge. A surface modification alters nanomaterials to determine the association between nanomaterials and biological interface. This procedure is significant to improve applications and to alleviate adverse effects. Nanomaterials are fabricated and functionalized with different moieties to decrease toxicity to human health. These moieties provide new physicochemical properties to nanomaterials with improved biocompatibility (34).

Shape, structure, and size (chemical and physical) are significant nanomaterials' elements associated with biological impacts and site of distribution and deposition within the body and clearance. Reactivity and surface charge are the parameters adapted to deliver a preferred functionality to a specified nanomaterial and influence distribution, clearance and deposition, and other inflammatory responses to the nanomaterial. Characterization of nanomaterials' 
physicochemical parameters is significant to the extreme possible extent to regulate the accurate dose-response materials' characteristics (35).

Nanomaterials exhibit possibilities based on physicochemical properties that regulate their performance in the biosystems to determine the cause of biochemical disturbance or homeostatic. Nanomaterials are well-established in the role to incorporate essential oils, for instance oregano oil or cinnamon for better use of edible film in the food packaging. Mostly, nanomaterials are made up of polymers and are used in food processing and food packaging. The role of better-nanostructured constituents in food sensing is the primary purpose of food processing to establish safe assessment and better food quality. These nanomaterials enhance the durability and flexibility of the contents of food. The nanomaterials can be consumed with beverages, drinks for consumption, and other food products (36).

Maintenance and improvement in health have been exhibited potentially by phytochemicals. These phytochemicals are also associated with the prevention and treatment of some diseases. Low stability, solubility, specificity, and target bioavailability somehow contain side effects when consumed at increased levels, limiting their use. Certainly, stability and solubility of phytochemicals are increased by nanoparticles with enhancement in absorption and protection from premature degradation and increase circulation time in the body. Furthermore, several nanoparticles reveal increased differential efficiency uptake in the tissue or target cells compared to normal tissue or cells by inhibiting nanoparticles from interacting prematurely with the biological environment and increasing permeation. Improvement in cellular uptake and retention impact in disease tissues and reduction in toxicity is exhibited by nanomaterials. Major biocompatible nanoparticles comprise lipid nanocarriers, poly (lactic-co-glycolic acid) nanoparticles, nanoliposomes, micelles, and nanoemulsions (37).

Starch-based nanoparticles (SNPs) have contributed much interest to protect, encapsulate, and provide bioactive components orally due to their vast ability, high biocompatibility, functionality, and environmental responsiveness. A wide variety of particle sizes can be used to synthesize SNPs with a broad range from few nanometers to hundred nanometers which approximately range from about $8-448 \mathrm{~nm}$. Comparison can be made with the dimensions of nucleic acids (5-100 nm long, $2 \mathrm{~nm}$ wide), viruses $(10-500 \mathrm{~nm})$, cell organelles $(5-100 \mathrm{~mm})$, and proteins $(1-10 \mathrm{~nm})$. The ability to adjust SNPs' properties and dimensions permits them to be utilized to build biological entities complexes, thus changing their performance in function. SNPs provide improvement in the hydrophobic substances solubility and bioactive nutritional attributes. For example, bioactive bioavailability is increased by SNPs. These nanomaterials are also designed to deliver to the same gastrointestinal tract regions (38).

Cellulose nanomaterials are extracted from renewable sources and impart exceptional biocompatibility and mechanical strength. Chemical and physical properties are associated with several nano-composite materials, which is an exciting prospect for application in the food, nutraceutical, and biomedical industries. Bio-nanomaterials linked with nanotechnology have incredible potential to utilize and enhance bioactive and nutrient absorption, pharmaceutical, nutraceutical field, and drug delivery systems through numerous applications (39). Synthesis of biocompatible nanomaterials and their interaction with the human body have been reported in Table $\mathbf{1}$.

Carbon and its allotropic forms are found to be biocompatible with the human body. Carbon nanoparticles possess exclusive biological activity based on the availability of free bonds on the surface of the carbon. In the present knowledge, graphene oxide and nanodiamond nanoparticles possess no substantial toxic impacts on animals. Carbon nanoparticle biocompatibility is associated with the nanoparticle biodistribution in internal organs. Carbon nanoparticle biocompatibility is an imperative element in food packaging selection (50).

Bioactive lipids like omega-3 fatty acids, fat-soluble vitamins, conjugated linoleic acids, phytosterols, and carotenoids are degraded chemically during storage of food or within the human gut due to the exposure to several stressors, such as oxygen, high temperatures, metabolic/digestive enzymes, moisture, light, and $\mathrm{pH}$ which decreases their bioavailability (51-53). Physiochemical stability, bioactive lipids bioavailability, and matrix compatibility are improved by nanotechnology. Certainty, food-grade ingredients are utilized to synthesize edible nanoparticles to participate in food applications effectively. Several kinds of delivery systems on the nanoscale (such as SLNs, Pickering emulsions, nanoemulsions, biopolymer nanogels, and nanoliposomes) are found to encapsulate various kinds of bioactive lipids effectively (e.g., carotenoids, oil-soluble vitamins, essential fatty acids, and phytosterols) (54).

An adequate understanding of links between biological systems and nanoparticles is required to improve safety standards and design new nanomaterials generations. The intracellular fate of engineered nanoparticles, molecular, cellular uptake mechanisms, and their potential distribution in the living organism must be examined. A strategy such as binding protein and opsonization has significant prominence because they strongly influence bio-distribution, cellular internalization, and nanoparticle immunogenicity in vivo and in vitro. Therefore, it is significant to explain the molecules' mechanisms associated with cellular uptake binding and NMs processing. Accumulation of NMs in the human body could be prevented. Therefore, they should be intended to be biocompatible to control their increased toxic effects while exposed by humans (55). The action mechanism of biocompatible nanomaterials in the human body has been represented in Figure 1.

\section{PROBLEMS OF NON-BIOCOMPATIBLE NANOMATERIALS}

Sanoj Rejinold et al. have investigated drug delivery for cancer through curcumin as bioactive ingredient and temperature sensitive biodegradable chitosan-g-poly ( $\mathrm{N}$-vinyl caprolactam) NPs (TRC-NPs) as vehicle. Heme assay was done by taking fresh blood to investigate the compatibility of blood for bare and curcumin-loaded TRC-NPs. Results revealed heme breakdown of $<5$ percent, and indicted a little damage to erythrocytes, according to ISO/TR 7406 (56). 
TABLE 1 | Biocompatibility of nanomaterials by consuming different nanofoods products.

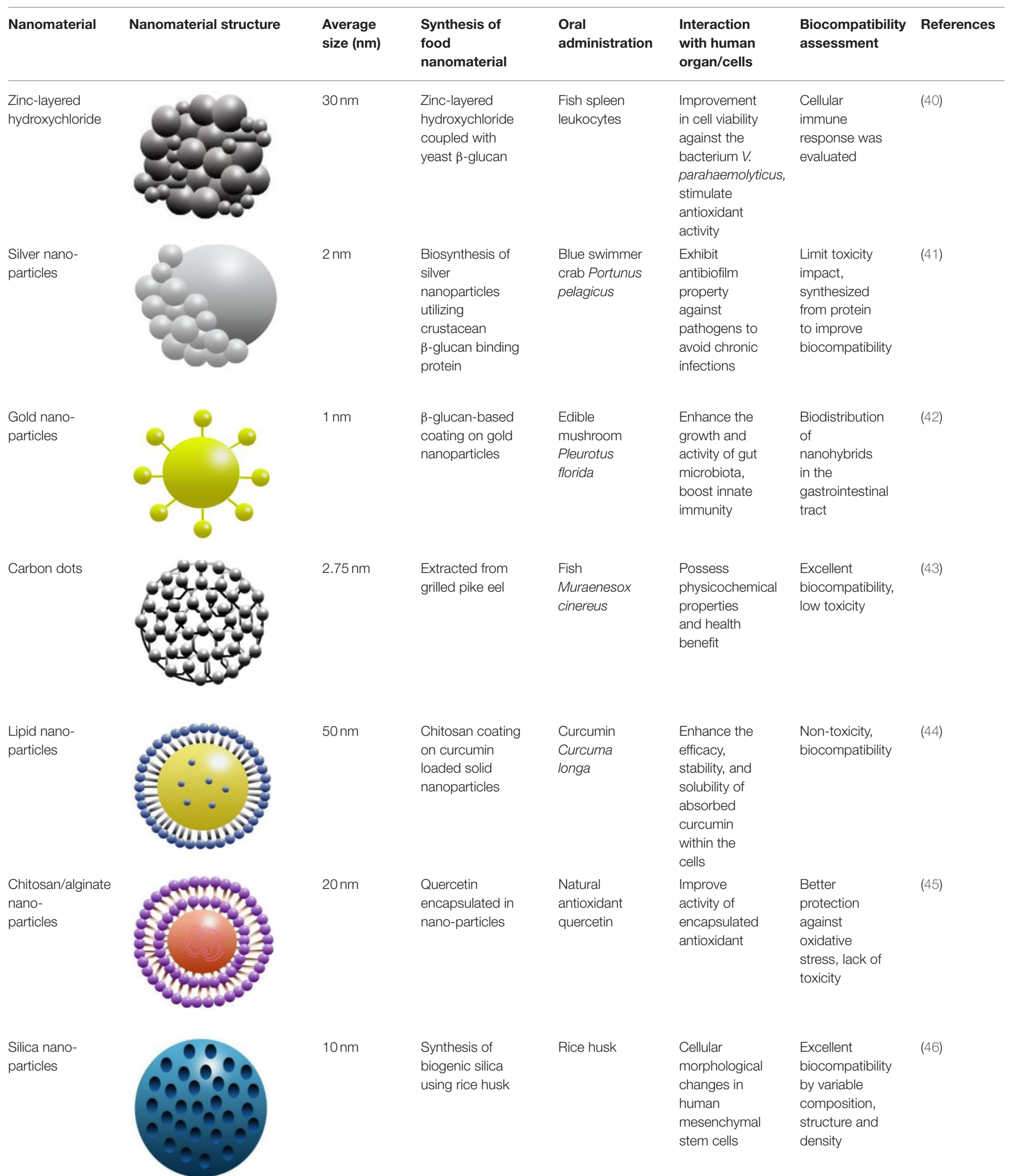


TABLE 1 | Continued

\begin{tabular}{|c|c|c|c|c|c|c|c|}
\hline Nanomaterial & Nanomaterial structure & $\begin{array}{l}\text { Average } \\
\text { size }(\mathrm{nm})\end{array}$ & $\begin{array}{l}\text { Synthesis of } \\
\text { food } \\
\text { nanomaterial }\end{array}$ & $\begin{array}{l}\text { Oral } \\
\text { administration }\end{array}$ & $\begin{array}{l}\text { Interaction } \\
\text { with human } \\
\text { organ/cells }\end{array}$ & $\begin{array}{l}\text { Biocompatibility } \\
\text { assessment }\end{array}$ & References \\
\hline $\begin{array}{l}\text { Protein based } \\
\text { silver } \\
\text { nanoparticles }\end{array}$ & & $135 \mathrm{~nm}$ & $\begin{array}{l}\text { Synthesized by } \\
\text { full cream milk } \\
\text { whey protein by } \\
\text { combining with } \\
\text { silver } \\
\text { nanoparticles }\end{array}$ & $\begin{array}{l}\text { Used in food } \\
\text { coatings }\end{array}$ & $\begin{array}{l}\text { Inhibit gram } \\
\text { negative } \\
\text { bacteria such } \\
\text { as } \\
\text { Escherichia } \\
\text { coli and } \\
\text { Salmonella } \\
\text { typhi as well } \\
\text { as gram } \\
\text { positive } \\
\text { bacteria } \\
\text { Staphylococcus } \\
\text { aureus and } \\
\text { Bacillus } \\
\text { subtilis }\end{array}$ & $\begin{array}{l}\text { Low toxicity, } \\
\text { effective to } \\
\text { use as } \\
\text { coating } \\
\text { material, high } \\
\text { biocompatibility, } \\
\text { and effective } \\
\text { to use in food } \\
\text { products }\end{array}$ & (48) \\
\hline $\begin{array}{l}\text { Polysaccharide } \\
\text { based } \\
\text { metallic nano- } \\
\text { particles }\end{array}$ & & $\begin{array}{l}10- \\
1,000 \mathrm{~nm}\end{array}$ & $\begin{array}{l}\text { Synthesized by } \\
\text { the combination } \\
\text { of gum arabic } \\
\text { (GA) and } \\
\text { chitosan (CS) }\end{array}$ & $\begin{array}{l}\text { Used as } \\
\text { packaging } \\
\text { material for } \\
\text { curcumin } \\
\text { encapsulation }\end{array}$ & $\begin{array}{l}\text { Prevent } \\
\text { oxidation of } \\
\text { curcumin and } \\
\text { active for the } \\
\text { release of } \\
\text { nano based } \\
\text { polysaccharide } \\
\text { in } \\
\text { gastrointestinal } \\
\text { tract }\end{array}$ & $\begin{array}{l}\text { Possess } \\
\text { excellent } \\
\text { biocompatibility } \\
\text { characteristics }\end{array}$ & (49) \\
\hline
\end{tabular}

Before approving nanomedicines for clinical use, experimental safety evidence, particularly negative impacts, is required (57). Higher generation dendrimers are the most hazardous. Cytotoxicity also relies on the surface charge, with cationic dendrimers being more hazardous than anionic dendrimers, which leads to apoptosis as a result of dysfunctioned mitochondria $(58,59)$. Carbon nanotubes are a revolutionary kind of nano-materials with several potential uses simultaneosuly poses adverse impacts on respiratory system. Agglomerated NPs can change physicochemical characteristics, affecting biological consequences (60).

\section{BIOCOMPATIBLE NANOMATERIALS IN FOOD PROCESSING}

Nanotechnology is applied in all sectors of food, including processing as well as production of functional foods, development of foods that are capable of modifying their color, flavor, or nutritional properties according to dietary needs of a person, along with the production of more assertive flavorings, colorings, and nutritional food additives (36). Moreover, this technology also lowers the costs of food additive ingredients and increases food products' shelf life (61). The food market needs technologies capable of assisting the market leadership in the industry of food processing to produce fresh, authentic, convenient, and flavorful products (62).

To obtain more information, the European Food Safety Authority (EFSA) commissioned RIKILT, and the Joint Research Center (JRC) organize a computational library of current and expected applications of NMs in the agriculture sector regarding production of feed and food as well as their safe and effective procedures to produce new food products. The primary purpose is to admire the safety concerns of nanomaterials (63-65). Currently, applications in the development of food additives from nanomaterials are prevailing. It is evident from EU and non-EU legislation that presently, the definition and specific provisions of NMs are incorporated in a few EU legal acts. In contrast, applying a broader approach provides guiding tools for the food industry in many non-EU countries (66).

Transformation in many research areas ranging from electronic and energy applications to environmental and 


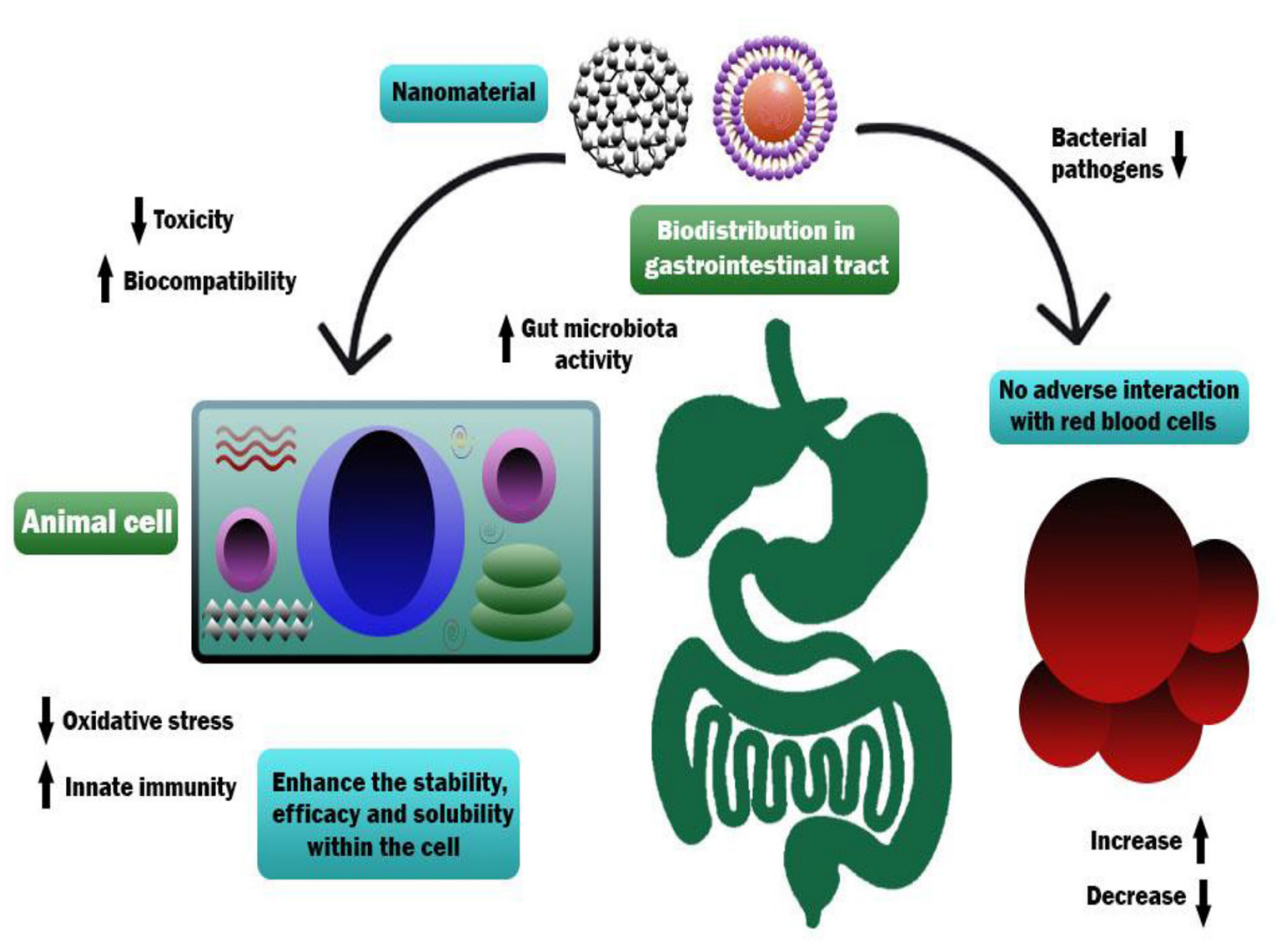

FIGURE 1 | Action mechanism of various biocompatible nanomaterials in human body.

biological disciplines is contributed by rapid development in nanomaterials synthesis, surface modification, and design. Nanomaterials have unique mechanical, chemical, biological, and physical properties. Food science is a multidisciplinary field incorporating chemistry, physics, biology, and engineering and has significant importance for life. It is an applied science dealing with food, particularly associated with the production area of food processing (67). Nanotechnology has evolved the concept of nano-phytomedicine; despite lag of regulatory standards, plant based medicines are being developed as these are naturally extracted and have no side effects so applying nanotechnology helps these to reach deep in cells, examples include drug delivery in cancer especially as nutraceuticals or functional foods (68). Neuroprotective phyto-active substances such as resveratrol, catechin, curcumin, quercetin, and ginsenosides may be bioavailable, stable, and dissolvable in the brain, but in-vivo investigations show their concentrations are too less to penetrate the blood-brain barrier. To circumvent these issues, nanophytomedicine with a regulated (1-100) $\mathrm{nm}$ size is employed (69).

Nano-technology provides enormous opportunities to enhance life quality through applied procedures in food systems and agriculture. Various advance agro- has been established, such as nano-fertilizers, biocontrol agent's nanoformulations, nanosensors, and nano-pesticides products based on nanotechnology, which is recently an extreme investigation subject. Numerous nanomaterials have been acclaimed in agriculture for use to assist in the reduction of agrochemicals consumption by the potential use of intelligent systems of delivery, which decrease the nutrient losses and enhance the yield through optimized nutrients and water management (70).

The food processing sector has been established by the potential application of biocompatible nanomaterials in food. Nanofoods i.e., coatings, biofilm, and emulsions after production are consumed by human beings (71). Encapsulation of food additives is tremendously increasing with an interest in utilizing nanomaterials (72). The nutritional value of food is also enhanced by the possible applications of nanomaterials in fertilizers which bring a vital strategy to improve health by consuming those food products (73).

The spray drying method has been increasingly applied in food products, such as in formula milk products used by babies, soluble cocoa powder in milk and powdered sweets for children and food-based supplements rich in vitamins, proteins, and minerals for adults. These products are formulated first in solution and then transformed into powders to assist in preservation for extended shelf life. Recently, innovative technologies like nanospray drying have been developed to produce food formulations with maximum cost effective yet highly bio-active substances (74). Encapsulation and drying of several food constituents such as minerals, carotenoids, essential oils, vitamins, fatty acids, and phenolic compounds are performed by potential nano spray dryers. Nano spray drying (NSD) involves the reduction of size for the uniform distribution. Nanoparticles are rearranged and collected by applying nanospray drying. Power dischargers and modified atomizers have 
been applied to increase the efficiency. NSD increases the yield of process to establish maximum attainability. Nono-encapsulated bioactive components revealed better efficacy and retention as compared to freely available ones in intestinal juice incase of catechins when studied for in vitro-digestion (75). Furr and Clark propose that carotenoids are taken up by biles salt complexes, which then transfer them to chylomicrons. Direct nanoparticle absorption can theoretically increase the efficacy of dissolved but partially assimilated minerals and nutraceuticals (76). Ratnam et al. advocate using nanoscale drug delivery systems for more polar molecules like isoflavones, and micro- and maybe even nanoscale particles as the most efficient approaches (77).

Nano-technology has begun to influence many scientific fields and industries, including food technology, meaningfully. Several nanosystems such as nanoliposomes, dendrimers, liposomes, emulsions, quantum dots, and nanotubes play a potential role in food processing. The development of nanoemulsions, nanobiofilms, coatings, and packaging films is due to the efficient nanotechnology and nanofilms (78). Nanofilms protect foods from dryness. Shelf life of food products enhanced by using containers lined by nano-film coated with silica nanoparticles. Nanofilms are really good barrier to moisture, oxygen and microbes. Silicate nano-particle coating makes it water repellant due to decline in surface energy and inlined coarseness of surface, this could further be enhanced by coating of hydrophobic layer (79). Layer by layer deposition of oppositely charged layer is the best technique to formulate a good nanofilm (80). Polysaccharides, gums, polypeptides, polymers, lipids, and their aggregates having antimicrobial properties are all examples of renewable/reuseable biopolymers derived from animals and plants. Triclosan a bioactive compound incorporated in polymer basically rubber is being sold as food container with brand name of Microban, Wasabi extract is being used as coated polyethylene terephthalate film after encapsulating in cyclodextrin which can be purchased as Wasapower (81).

Essential oil-coated films which have been explored extensively include garlic oil, rosemary, cinnamaldehyde and allyl isothiocyanate (AIT) (82-85). Researchers have developed efficient nano-preservatives (NPRs) having diverse applications. However, the literature available on food preservation based on nanotechnology does not include molecular perspectives involved in food preservation. To design edible coatings, nanotechnology, and interface domain which is concerned with the physics of intermolecular and interfacial forces, contribute a lot, and there is a significant knowledge gap in this domain. To develop efficient NPRs, identification of contributing factors at nano and molecular level is needed urgently. Moreover, in terms of public interest it is important to understand the impacts of NPRs on health (86). Edible nano-coatings are now being utilized not just for shelf life improvement.

\section{BIOCOMPATIBLE NANOMATERIALS IN FOOD SAFETY AND QUALITY}

To detect tiny amounts of contaminants, viruses, or bacteria, the development of analytical methods is another important use of nanotechnology. This will enhance the safety to the food processing system. Regulatory systems are needed urgently to manage any risks involved with nanofoods and the use of nanotechnology. Due to the growing demand for enhanced shelf life and protection from various foodborne diseases, it is expected that many areas of food science can be transformed using nanotechnology (87).

The shelf life of Fragaria ananassa (strawberry) and Citrus limon (lemon) is enhanced when Silver nano-particles in poly(vinyl alcohol) matrix (AgPVA) nanofiber is surface-coated over these fruits, AgNPs were developed by extracts from black currents peels (88). Thymus vulgaris (Thyme) leaf extract has been used to develop phytochemicals stabilized zinc oxide $(\mathrm{ZnO})$ nanoparticles that have also pronounced antimicrobial properties against gram-negative bacteria. In recent years, a promising trend regarding the screening use of NMs as adsorbents has been observed in food safety $(88,89)$.

Prolonged shelf life and freshness, along with the quality of the food products, are the targets. Knowledge is increasing significantly as much work is done by biologists, chemists, technologists, physicists, and ecologists, particularly in nanotechnology; however, little is known about many aspects like the interactions with plant biomolecules. Organic and inorganic materials are used to synthesize nanomaterials, and their size is between 0.2 and $100 \mathrm{~nm}$. Biocompatible nanomaterials aid in developing more innovative gadgets to meet the upcoming challenges in food technology (90).

Evaluation of various nanomaterials (NMs) in food sample pretreatment like metal-organic frameworks (MOFs) has been done. Covalent-organic frameworks (COFs), ordered mesoporous silicas (OMSs), polydopamine-derived materials (PDA), materials based on carbon, molecularly imprinted polymers, as well as other novel nanomaterials are being used for this purpose. When conventional adsorbents are compared, excellent performance is shown by the functional nanomaterials in terms of removal and pre-concentration of contaminants from food, resulting in a significant improvement in accuracy, detection, precision, selectivity, and sensitivity. Up till now, as far as biological and environmental samples are concerned, summarization of the applications of nanomaterials as solid-phase extraction adsorbents has been well-presented (21).

Nanostructures can rapidly and directly detect diseaserelated biomarkers, like nanotubes, nanowires, nanoparticles, microarrays, cantilevers, and nanoarrays, as part of an accurate process of sample and significantly increased sensitivity. There is the requirement of accurate techniques regarding identifying and detecting pathogenic bacteria, thus assuring food safety. A unique combination of magnetic nanoparticles and diverse carbohydrate bioactivities is needed to develop a safety system based on magnetic glyco-nanoparticle (MGNP). MGNPs are used for the first time to detect, quantify, and differentiate $E$. coli cells and can provide a new arena for applications in decontamination and food safety $(91,92)$.

To guarantee that food reaches the consumers in the best possible conditions in terms of freshness and microbiology, food safety and quality are considered important features. These aspects are secured and enhanced by nanotechnology. 
Fortification of food with bio-actives and controlled and targeted release in the gut is provided by novel technologies like nanofabrication and nanoencapsulation. Food quality can also be enhanced by the direct addition of nanomaterials into the food matrix or materials which come in contact with food $(18,93)$.

Incorporation of nanomaterials in packaging can be done in nano-composites by solvent casting, melt compounding, and lamination or electrohydrodynamic processing (EHDP). Active, passive, and even bioactive properties are promoted by it. These characteristics include anti-oxidation, antibacterial, barrier, and oxygen scavenging roles, and the controlled release of functional ingredients. The envisioned or non-intended movement of the nano-sized materials or the active ingredients they may transfer can be achieved. Lastly, unique opportunities in circular bio-economy strategies concerning valorization were provided by applying nanomaterials like agro-industrial wastes and byproducts of food processing (94).

Various challenges in the food industry are met by nanotechnology. The use of nanotechnology meets the demand of the public regarding healthier and safer products. It provides the solution to several challenges, due to which it is regarded as a rapidly developing toolbox. The inclusion of nanomaterials in food products and packaging is because of their diversity and vast and tunable functionality. Bioactive fortification and prebiotics encapsulation helps to enhance the nutritional quality, and their antimicrobial and sensing properties help increase safety and confer novel sensorial properties. In this communication of food nanotechnology, matrix materials, particularly foodgrade components, present and future production mechanisms, and in the fields of food preservation, safety and quality, bio-accessibility of nutrients and digestibility, current and potential applications have been mentioned in detail $(95,96)$. Nanostructures help promote safety of food as well as fortifying, along with bioavailability, processing, and encapsulation of active chemicals (97).

\section{BIOCOMPATIBLE NANOMATERIALS IN FOOD PACKAGING}

The use of nanomaterials in many foods and food sector-related disciplines offers significant potential properties, including processing, preservation, analysis, safety and delivery of food, and active and intelligent packaging. Innovative strategy requires the development of packaging having antimicrobial properties using polymer embedded nanomaterials. The commercial demand for silver nanoparticles is increasing due to their multiple beneficial uses in the market. The total use of these materials is in food-based products because of their antimicrobial properties. To counter a broad range of pathogenic organisms' silver nanoparticles are of prime importance as they are essential in evolving new antimicrobial agents (98). The use of developing technologies like as nanotechnology and antimicrobial packaging to effectively include biologically active chemicals and enhance planned functionalities i.e., smart biosensors is now trending in research and development for food packages manufacturing industries (99).
Recently, biological synthesis by using plant extracts to synthesize metal nanoparticles has been successfully performed. This investigation indicated the potential utilization of extracts from $P$. serratum leaves as an excellent bio-resource for the biosynthesis and diverse implementation of silver nanoparticles (AgNPs), more importantly in the packaging of food as an antibacterial agent and preservation against various foodborne pathogenic microbes. AgPVA nanofibers are used in antimicrobial packaging for food preservation in better manner (35).

Potential use of nanomaterials in various food science sectors has been found recently, including nano-sensor, packaging materials, encapsulated food components, etc. Nanomaterials based on polymers, liposomes, etc., are utilized in this sector due to their solubility, bioavailability, controlled release, etc. Antibacterial activity of the nanomaterials is associated with antibacterial mechanisms, including oxygen species, membrane damage, etc., in the domain of food science. The use of nanomaterials in food packaging is suitable as they exhibit enhanced barrier, mechanical and heat resistivity, and easy biodegradability (100).

Nanomaterials play an important part role in protecting, preserve foods and increase the shelf life. The use of pesticides, chemical or biological contaminants, and lifestyle changes directly affects food quality. Products having antimicrobial activity along with enhanced shelf life are produced by using microfibrillated cellulose nanomaterials (MCNs). Special attention is given to MCNs by researchers due to the prevention of microbial growth. It is possible to combine biopolymers/polymers with various MCNs, which act as a vehicle for individual particles and as a hybrid system allowing natural compounds and metallic nano-compounds. However, risk evaluation is needed to use nanoparticles in food packaging $(101,102)$.

Designing and developing various efficient food preservatives is one of the essential aspects of this field. However, due to the shortcomings of the bulk forms of such preservatives, research is in progress to find suitable alternatives to replace conventional modalities. In almost every aspect of food preservation, the approach has been made feasible with the intervention of nanotechnology. Over the past few decades, this domain of nanobiotechnology has been explored very well, and tremendous literature has been reported $(103,104)$.

Researchers have developed efficient nano-particles (NPs) having diverse applications. However, the literature available on food preservation based on nanotechnology does not include molecular perspectives involved in food preservation. To design edible coatings, nanotechnology and interface domain which is concerned with the physics of intermolecular and interfacial forces, contribute a lot, and there is a significant knowledge gap in this domain. To develop efficient NPs, identification of contributing factors at the nano and molecular levels is needed urgently. Moreover, it is essential to understand the impacts of NPs on health (105).

Various materials like nanoclay, nanosphere, nanowire, nanoceramic, nanoemulsion, nanotube, membrane, nanocapsule, and liposomal nanovesicle are used as packaging 
material for food. In packaged foods, biopolymers/natural hydrocolloids have been used because of their non-toxic nature and biodegradability to overcome environmental hazards. In addition to these positive effects, they also have some demerits like poorbarrier to moisture and harnessed mechanical properties. Due to their exceptional properties, interest in nanomaterials has been increased over the past few years (106). As they are capable of increasing thermal, mechanical, and gas barrier properties, they are used as precedent in food packaging without compromising their non-toxic and biodegradable ability. In food packaging, nanoparticles of zinc oxide, titanium dioxide and silver, kaolinite, montmorillonite (MMT), and coated silicate are used. They are considered important because films coated with these nanomaterials provide an excellent barrier against carbon dioxide, oxygen, and flavor compounds. They also possess antimicrobial activity, oxygen scavenging capability, and temperature tolerance. The most challenging task regarding the production of such nano-composites is their complete distribution within the polymer matrix and their compatibility. Therefore, enhanced performance of nano-packaging materials is demanded increasingly, including degradability, mechanical stability, and effectiveness of antibacterial property (107).

In the food sector importance of nanotechnology is increasing, particularly in food packaging and safety. Improvement in the barrier properties of packaging materials is expected with the incorporation of nanomaterials into packaging. The use of valuable raw materials and the generation of waste will also get reduced. In fresh fruits and food is protected from offflavors and odors, lipids, gases, and moisture by the use of edible nanolaminates such as starch for encapsulation of pre and probiotics, vitamins, and drug delivery purposes natural biopolymers such as polysaccharides of nano-size can be used (108-110). As the process is time-consuming and laborious, these are the most critical problems in the food sector regarding the analysis of food quality control. To facilitate the preparation and analysis of food samples state of the art devices and methods are being developed. To detect microorganisms and contaminants, developing nano-sensors is an excellent application of food nanotechnology (111).

Significant barrier properties and catalytic, mechanical, optical, and antimicrobial properties can be induced into packaging with the help of nanotechnology. The majority of the packaging incorporating nanotechnology available in the market is based on silver nanoparticles (AgNPs) and nanoclay. Others, like nano-zinc oxide $(\mathrm{ZnO})$ and titanium, share less in the current market. The use of nanomaterials in current food packaging is to induce antimicrobial function and enhance barrier functions. Thus, shelf life and freshness of the food gets enhanced (112).

\section{BIOACTIVE RETENTION AND BIOAVAILABILITY OF NANOCAPSULES AND GASTRIC CONDITIONS AFTER PROCESSING}

The bioactive component's retention and bioavailability of nanocapsules made from different nanomaterials along with gastric conditions after processing in gut can be viewed in Table 2.

\section{CURRENT DEVELOPMENTS}

Recent developments are mainly based on medicine, among which stand out Amphotericin B which is a bioactive against fungal infections, and is being developed using Liposomesnanotechnology approach by Gilead Sciences International Ltd., Uxbridge, UK, in form of suspension and marketed as AmBisome. Inactivated hepatitis A virus is being developed using virosomes-nanotechnology approach, and sold as suspension form vaccine under brandname Epaxal by Crucell Spain SA Madrid. A very common nano-medicine for iron deficiency anemia, Venofer is basically a nano-complex of Iron sucrose (iron (III)-hydroxide sucrose, is developed by Vifor in France and distributed to whole world (116).

\section{LEGISLATIONS AND REGULATIONS FOR NANO-PRODUCTS}

Environmental legislation and rules address the usage, reusing, recycling, and certification of package materials. All food, feed, food packaging developing and waste managing have to follow 13th version of US EPA's Waste Reduction Model (117). In USA, Food and Drug Administration regulates and legislates the nanotechnology incorporated food, feed itself and packaging be it edible or non-edible also degradable or non-degradable. In 2017 this acclaimed organization developed rules and binding guidelines for use of nanotechnology and nanomaterials in products, packaging or systems and defined to investigate items as unique in existence and usage targeting case to case variations. Every food and drug developed by using nanotechnology must pass by FDA, otherwise could not be brought to market as to avoid health problems (118). European Union Observatory for Nanomaterials legislates alongwith other regulatory bodies on which products are safe as nanoproducts after prel-launch clinical investigations in UK and EU countries through Registration, Evaluation, Authorisation and Restriction of Chemicals (REACH) and Classification, Labeling and Packaging regulation (119).

\section{HEALTH AND SAFETY CONCERNS, TOXICITY, AND PUBLIC PERCEPTION FOR USING NANOTECHNOLOGY IN FOODS}

The migration of nanomaterials in the foodstuff is increasing as it can pose serious risks. Their market growth is hindered by insufficient information about the assessment of environmental and human safety. To overcome this difficulty, it is believed by the public that legislation from the government is essential. The characteristics and functions of significant nanomaterials commonly applied in food packaging, including their present and potential products, migration research, safety issues, and public concerns, are significant drives for nanomaterials development 
TABLE 2 | Comprehensive insight to the bioactive component's retention and bioavailability of nanocapsules.

\begin{tabular}{|c|c|c|c|c|c|c|c|}
\hline Nanomaterial & Nanomaterial structure & $\begin{array}{l}\text { Average } \\
\text { size }(\mathrm{nm})\end{array}$ & $\begin{array}{l}\text { Synthesis of } \\
\text { food } \\
\text { nanomaterial }\end{array}$ & $\begin{array}{l}\text { Oral } \\
\text { administration }\end{array}$ & $\begin{array}{l}\text { Interaction } \\
\text { with human } \\
\text { organ/cells }\end{array}$ & $\begin{array}{l}\text { Biocompatibility } \\
\text { assessment }\end{array}$ & References \\
\hline Nanocapsule & & $<0.2 \mu \mathrm{m}$ & $\begin{array}{l}\text { Sodium alginate } \\
\text { concentration is } \\
\text { used to prepare } \\
\text { nanoencapsulated } \\
\text { quercetin }\end{array}$ & $\begin{array}{l}\text { Nanoencapsulated } \\
\text { bioactive } \\
\text { compound } \\
\text { quercetin }\end{array}$ & $\begin{array}{l}\text { Prevent low } \\
\text { gastric pH } \\
\text { and during } \\
\text { the digestion } \\
\text { process } \\
\text { optimize their } \\
\text { release }\end{array}$ & $\begin{array}{l}\text { Showed } \\
\text { absent or low } \\
\text { toxicity in vitro } \\
\text { in different cell } \\
\text { models and } \\
\text { improved the } \\
\text { bioavailability }\end{array}$ & (113) \\
\hline Nanoliposomes & & $10 \mathrm{~nm}$ & $\begin{array}{l}\text { Prepared by } \\
\text { scattering the } \\
\text { lipids in media } \\
\text { that is aqueous } \\
\text { and by purifying } \\
\text { and analyzing }\end{array}$ & $\begin{array}{l}\text { Nanoencapsulated } \\
\text { curcumin }\end{array}$ & $\begin{array}{l}\text { Interact with } \\
\text { intestine by } \\
\text { bile salts } \\
\text { without the } \\
\text { dispersion } \\
\text { owing to their } \\
\text { extra small } \\
\text { size }\end{array}$ & $\begin{array}{l}\text { Enhanced } \\
\text { nutrients' } \\
\text { bioavailability, } \\
\text { safety of food, } \\
\text { and improved } \\
\text { bioaccessibility }\end{array}$ & (114) \\
\hline $\begin{array}{l}\text { Starch } \\
\text { nanoparticles }\end{array}$ & & $322.7 \mathrm{~nm}$ & $\begin{array}{l}\text { Obtained from } \\
\text { lotus stem }\end{array}$ & $\begin{array}{l}\text { Nanoencapsulated } \\
\text { catechin }\end{array}$ & $\begin{array}{l}\text { Provide } \\
\text { controlled } \\
\text { intestinal } \\
\text { release }\end{array}$ & $\begin{array}{l}\text { Availability of } \\
\text { high bioactive } \\
\text { compounds, } \\
\text { prevent } \\
\text { various } \\
\text { diseases }\end{array}$ & (75) \\
\hline $\begin{array}{l}\text { Nanostructured } \\
\text { lipid capsules }\end{array}$ & & $\begin{array}{l}50- \\
300 \mathrm{~nm}\end{array}$ & $\begin{array}{l}\text { Formed by } \\
\text { interaction with } \\
\text { various } \\
\text { polyphenols } \\
\text { such as catechin }\end{array}$ & $\begin{array}{l}\text { Nanoencapsulation } \\
\text { of } \\
\text { polyphenols }\end{array}$ & $\begin{array}{l}\text { Enhanced } \\
\text { oral } \\
\text { bioavailability } \\
\text { and interact } \\
\text { with } \\
\text { gastrointestinal } \\
\text { tract to gain } \\
\text { high stability }\end{array}$ & $\begin{array}{l}\text { Provide } \\
\text { physiological } \\
\text { treatment of } \\
\text { several } \\
\text { organs by } \\
\text { acting as } \\
\text { dietary } \\
\text { supplements }\end{array}$ & (115) \\
\hline
\end{tabular}

$(81,120)$. Nano-foods is a burgeoning field, yet toxicity of nanomaterials is a major concern, a study by De Angelis and team maintained that nanoporous silicon based nano-particles of $2 \mathrm{~nm}$ pore size posed no histopathological injury in model mouse and exhibited zero toxicity; similar results were depicted by Park and co-scientists regarding toxicity of luminescent silver nanoparticles $(121,122)$.

Spoilage is a significant concern regarding food due to improper packaging technologies. Food packaging is expected to improve by nanotechnology. Packaging materials based on nanotechnology have unique properties, including antimicrobial potential, oxygen scavengers, barriers to the gas, or moisture, etc. Shelf life gets increased by using nanomaterials in food packaging without any unwanted change in its quality. The use of nano-based packaging of food is still in its initial stages, and hence, this review focuses on advances and an overview of the current status in the field. Various attempts have also been made to address safety and toxicity-related issues regarding public perceptions about nanomaterials and essential research areas in the field. The knowledge of positive and negative aspects of this technology will therefore define their acceptability as a sustainable material for packaging food $(19,123)$. Perception about nanotechnology in research published by Isabella and her team, depicts a negative notion in the minds of females to use it in cosmetics and dietary components as compared to males, so basically its application area of nanotechnology utility that concerns, simultaneously females were more keen to learn about the impact of nanotechnology as compared to males and they wanted to see it in product information label as if nanotechnology was involved at any level during processing (124). The expansion of awareness about scientific implications and reduction of negative perception about nanotechnology applications in daily 
life usage can be done by knowledge dissemination through events and community participation inclination in such activities to highlight benefits and risks of nanoparticles. Consumers are concerned about staying updated on the risks and benefits of using nanofoods (125).

\section{CONCLUSION}

Nanotechnology applications are proliferating in food science and industry disciplines, which are among the fastest-growing and most promising areas of nanomaterial/nanotechnology applications. In the food sector, the development of innovative applications depends on advanced strategies like nanotechnology. Soon, biocompatible nanomaterials are expected to increase and therefore it has become an imperative technology for human exposure, especially by food consumption. Bio nano-composite materials open a door for the usage of the novel, high-performance, lightweight, and ecofriendly materials instead of traditional, non-biodegradable plastic packaging materials. Environmental hazards can be resolved due to the non-toxicity and biodegradability of various biopolymers such as polysaccharides like carboxymethyl cellulose (CMC), chitosan (CS), cellophane, and starch. Nanotechnology is an innovative technology and holds the potential to enhance food quality and safety. Biocompatible nanomaterials are being utilized in numerous areas of the food industry to explore their non-toxicity effects on the human body. There is a dire need for global standard legislations and testing protocols for nanoproducts.

\section{FUTURE RECOMMENDATION}

Through novel applications of nanotechnology, nanomaterials possess the excellent potential to increase the supply of food, including the absorption of nutrient and bioactive as well as systems for delivery; functionality of ingredients; enhanced

\section{REFERENCES}

1. Ranjha MMAN, Shafique B, Wang L, Irfan S, Safdar MN, Murtaza MA, et al. A comprehensive review on phytochemistry, bioactivity and medicinal value of bioactive compounds of pomegranate (Punica granatum). Adv Tradit Med. (2021) 21:1-21.

2. Ranjha MMAN, Kanwal R, Shafique B, Arshad RN, Irfan S, Kieliszek $\mathrm{M}$, et al. A critical review on pulsed electric field: a novel technology for the extraction of phytoconstituents. Molecules. (2021) 26:1-23. doi: 10.3390/molecules26164893

3. Ranjha MMAN, Irfan S, Lorenzo JM, Shafique B, Kanwal R, Pateiro M, et al. Sonication, a potential technique for extraction of phytoconstituents: a systematic review. Process. (2021) 9:1-21. doi: 10.3390/pr9081406

4. Adabi M, Naghibzadeh M, Adabi M, Zarrinfard MA, Esnaashari SS, Seifalian AM, et al. Biocompatibility and nanostructured materials: applications in nanomedicine. Art Cells Nanomed Biotech. (2016) 45:833-42. doi: 10.1080/21691401.2016.1178134

5. Aschberger K, Gottardo S, Amenta V, Arena M, Botelho Moniz $\mathrm{F}$, Bouwmeester $\mathrm{H}$, et al. Nanomaterials in food-current and future applications and regulatory aspects. In J Phy Conf Ser. (2015) 617:012032. doi: 10.1088/1742-6596/617/1/012032

6. Kumar AP, Depan D, Singh Tomer N, Singh RP. Nanoscale particles for polymer degradation and stabilization-trends and future perspectives. colors and flavors; detection and control of microbes, allergens, and contaminants; and properties and performance of food packaging. Further studies are still needed to overcome important safety challenges and provide information on the risks and hazards of nanomaterials used in the food industry. The fundamental aspects of preservation of food future direction, molecular aspects, safety, and applicability of nano-preservatives should also be discussed.

\section{AUTHOR CONTRIBUTIONS}

MR, BS, and AR: methodology. SI, AS, and SS: validation. AM, AA, and UR: investigation. UR, SI, and SS: resources. MR, BS, SZ, AM, AA, UR, and AR: data curation. SS, MR, UR, BS, AM, AA, and AR: writing-original draft preparation. MR, BS, AM, AA, AR, UR, and SS: writing-review and editing. SI, UR, and AS: visualization. SI and AS: supervision and project administration. SI: funding acquisition. All authors have read and agreed to the published version of the manuscript.

\section{FUNDING}

This work was funded in part by the USDA/NIFA through the Agricultural Research Program at North Carolina Agricultural and Technical State University (Evans-Allen Program, project number NC.X-291-5-15-170-1) and by an 1890 Capacity Building Program Grant (No. 2020-38821-31113/project accession No. 021765). SI would like to acknowledge the support of the Agricultural Research Station at North Carolina Agricultural and Technical State University (Greensboro, NC 27411, USA). This research was funded, in part, by grants (project Nos. NC.X337-5-21-170-1 and NC.X341-5-21-170-1) from the National Institute of Food and Agriculture (NIFA). Its contents are solely the responsibility of the authors and do not necessarily represent the official views of NIFA.

Prog Polym Sci. (2009) 34:479-515. doi: 10.1016/j.progpolymsci.2009. 01.002

7. Chawla P, Kumar N, Kaushik R, Dhull SB. Synthesis, characterization and cellular mineral absorption of nanoemulsions of Rhododendron arboreum flower extracts stabilized with gum arabic. J Food Sci Technol. (2019) 56:5194-203. doi: 10.1007/s13197-019-03988-z

8. Chawla P, Kumar N, Bains A, Dhull SB, Kumar M, Kaushik $\mathrm{R}$, et al. Gum arabic capped copper nanoparticles: synthesis, characterization, and applications. Int J Biol Macromol. (2020) 146:232-42. doi: 10.1016/j.ijbiomac.2019.12.260

9. Dhull SB, Chawla P, Kaushik R. Nanotechnological Approaches in Food Microbiology. Boca Raton, FL: CRC Press (2020).

10. Panghal A, Chhikara N, Anshid V, Sai Charan MV, Surendran V, Malik A, et al. Nanoemulsions: a promising tool for dairy sector. Nanotechnol Life Sci. (2019) 4:99-117. doi: 10.1007/978-3-030-17061-5_4

11. Naz S, Shahzad H, Ali A, Zia M. Nanomaterials as nanocarriers: a critical assessment why these are multi-chore vanquisher in breast cancer treatment. Artif Cells Nanomed Biotechnol. (2017) 46:899-916. doi: 10.1080/21691401.2017.1375937

12. Nadeem M, Ghaffar A, Hashim MM, Murtaza MA, Ranjha MMAN, Mehmood A, et al. Sonication and microwave processing of phalsa drink: a synergistic approach. Int J Fruit Sci. (2021) 21:993-1007. doi: $10.1080 / 15538362.2021 .1965942$ 
13. Nadeem HR, Akhtar S, Ismail T, Sestili P, Lorenzo JM, Ranjha MM, et al. Heterocyclic aromatic amines in meat: formation, isolation. risk assessment, and inhibitory effect of plant extracts. Foods. (2021) 10:1466. doi: 10.3390/foods10071466

14. Ranjha MMAN, Irfan S, Nadeem M, Mahmood SA. Comprehensive review on nutritional value. medicinal uses, and processing of banana. Food Rev Int. (2020). doi: 10.1080/87559129.2020.1725890

15. Ranjha MMAN, Amjad S, Ashraf S, Khawar L, Safdar MN, Jabbar S, et al. Extraction of polyphenols from apple and pomegranate peels employing different extraction techniques for the development of functional date bars. Int J Fruit Sci. (2020) 20:S1201-21. doi: 10.1080/15538362.2020.1782804

16. Bains A, Narang D, Chawla P, Dhull SB. Mushroom extract-reduced metal nanoparticles : an effective approach against food pathogenic bacteria. Nanotechnol Approaches Food Microbiol. (2020) 2:31-53. doi: 10.1201/9780429342776-2

17. Bains A, Narang D, Chawla P, Dhull SB. Nanoparticles and antibiotic drug composite : a novel approach towards antimicrobial activity. Nanotechnol Approaches Food Microbiol. (2020) 7:165-86. doi: 10.1201/9780429342776-7

18. Huang Y, Mei L, Chen X, Wang Q. Recent developments in food packaging based on nanomaterials. Nanomater. (2018) 8:830. doi: 10.3390/nano8100830

19. Silvestre C, Duraccio D, Cimmino S. Food packaging based on polymer nanomaterials. Prog Polym Sci. (2011) 36:1766-82. doi: 10.1016/j.progpolymsci.2011.02.003

20. Bajpai VK, Kamle M, Shukla S, Mahato DK, Chandra P, Hwang SK, et al. Prospects of using nanotechnology for food preservation, safety, and security. J Food Drug Anal. (2018) 26:1201-14. doi: 10.1016/j.jfda.2018.06.011

21. Kritchenkov AS, Egorov AR, Dubashynskaya NV, Volkova OV, Zabodalova LA, Suchkova EP, et al. Natural polysaccharide-based smart (temperature sensing) and active (antibacterial, antioxidant and photoprotective) nanoparticles with potential application in biocompatible food coatings. Int J Biol Macromol. (2019) 134:480-6. doi: 10.1016/j.ijbiomac.2019. 04.194

22. Foster EJ, Moon RJ, Agarwal UP, Bortner MJ, Bras J, Camarero-Espinosa S, et al. Current characterization methods for cellulose nanomaterials. Chem Soc Rev. (2018) 47:2609-79. doi: 10.1039/C6CS00895J

23. Dasgupta N, Ranjan S, Mundekkad D, Ramalingam C, Shanker R, Kumar A. Nanotechnology in agro-food: from field to plate. Food Res Int. (2015) 69:381-400. doi: 10.1016/j.foodres.2015.01.005

24. Fao/Who FAO/WHO. Expert Meeting on the Application of Nanotechnologies in the Food and Agriculture Sectors: Potential Food Safety Implications: Meeting Report. Jt. FAO/WHO Act. Nanotechnologies. (2010). p. 134.

25. Bhushan B. Introduction to nanotechnology. Springer Handb Nanotechnol. (2010) 9:1-13. doi: 10.1007/978-3-642-02525-9

26. Rashidi L, Khosravi-Darani K. The applications of nanotechnology in food industry. Front Microbiol. (2011) 51:723-30. doi: 10.1080/10408391003785417

27. www.nanowerk.com. Nanotechnology in Food. Available online at: https:// www.nanowerk.com/nanotechnology-in-food.php (accessed November 3, 2021).

28. Ameta SK, Rai AK, Hiran D, Ameta R, Ameta SC. Use of nanomaterials in food science. Biog Nano-Particles Use Agro Ecosyst. (2020) 457:24. doi: 10.1007/978-981-15-2985-6_24

29. Bouwmeester H, Brandhoff P, Marvin HJP, Weigel S, Peters RJB. State of the safety assessment and current use of nanomaterials in food and food production. Trends Food Sci Technol. (2014) 40:200-10. doi: 10.1016/j.tifs.2014.08.009

30. Ahmad M, Gani A. Development of novel functional snacks containing nano-encapsulated resveratrol with anti-diabetic, antiobesity and antioxidant properties. Food Chem. (2021) 352:129323. doi: 10.1016/j.foodchem.2021.129323

31. Luo Y, Wang Q, Zhang Y. Biopolymer-based nanotechnology approaches to deliver bioactive compounds for food applications: a perspective on the past, present, and future. J Agric Food Chem. (2020) 68:12993-3000. doi: 10.1021/acs.jafc.0c00277

32. Wang Z, Ma G, Zhang J, Lin W, Ji F, Bernards MT, et al. Development of zwitterionic polymer-based doxorubicin conjugates: tuning the surface charge to prolong the circulation and reduce toxicity. Langmuir. (2014) 30:3764-74. doi: 10.1021/la5000765

33. Xue X, Zhou Z, Peng B, Zhu MM, Zhang YJ, Ren W, et al. Review on nanomaterials synthesized by vapor transport method: growth and their related applications. RSC Adv. (2015) 5:79249-63. doi: 10.1039/C5RA13349A

34. Sajid M, Ilyas M, Basheer C, Tariq M, Daud M, Baig N, et al. Impact of nanoparticles on human and environment: review of toxicity factors, exposures, control strategies, and future prospects. Environ Sci Pollut Res. (2014) 22:4122-43. doi: 10.1007/s11356-014-3994-1

35. Magnuson BA, Jonaitis TS, Card JW. A brief review of the occurrence, use, and safety of food-related nanomaterials. J Food Sci. (2011) 76:R12633.doi: 10.1111/j.1750-3841.2011.02170.x

36. Kumar LY. Role and adverse effects of nanomaterials in food technology. $J$ Toxicol Heal. (2015) 2:2. doi: 10.7243/2056-3779-2-2

37. Wang S, Su R, Nie S, Sun M, Zhang J, Wu D, et al. Application of nanotechnology in improving bioavailability and bioactivity of diet-derived phytochemicals. J Nutr Biochem. (2014) 25:363. doi: 10.1016/j.jnutbio.2013.10.002

38. Qiu C, Wang C, Gong C, McClements DJ, Jin Z, Wang J. Advances in research on preparation, characterization, interaction with proteins, digestion and delivery systems of starch-based nanoparticles. Int $\mathrm{J} \mathrm{Biol}$ Macromol. (2020) 152:117-25. doi: 10.1016/j.ijbiomac.2020.02.156

39. Amalraj A, Gopi S, Thomas S, Haponiuk JT. Cellulose nanomaterials in biomedical, food, and nutraceutical applications: a review. Macromol Symp. (2018) 380:1800115. doi: 10.1002/masy.201800115

40. Velazquez-Carriles C, Macias-Rodríguez ME, Carbajal-Arizaga GG, Silva-Jara J, Angulo C, Reyes-Becerril M. Immobilizing yeast $\beta$-glucan on zinc-layered hydroxide nanoparticle improves innate immune response in fish leukocytes. Fish Shellfish Immunol. (2018) 82:504-13. doi: 10.1016/j.fsi.2018.08.055

41. Anjugam M, Vaseeharan B, Iswarya A, Divya M, Prabhu NM, Sankaranarayanan K. Biological synthesis of silver nanoparticles using $\beta-1,3$ glucan binding protein and their antibacterial, antibiofilm and cytotoxic potential. Microb Pathog. (2018) 115:31-40. doi: 10.1016/j.micpath.2017.12.003

42. Li X, Chi P, Cheung K. Application of natural $\beta$-glucans as biocompatible functional nanomaterials-NC-ND. Food Sci Hum Wellness. (2019) 8:315-9. doi: 10.1016/j.fshw.2019.11.005

43. Bi J, Li Y, Wang H, Song Y, Cong S, Li D, et al. Physicochemical properties and cytotoxicity of carbon dots in grilled fish. New J Chem. (2017) 41:8490-6. doi: 10.1039/C7NJ02163A

44. Ramalingam P, Yoo SW, Ko YT. Nanodelivery systems based on mucoadhesive polymer coated solid lipid nanoparticles to improve the oral intake of food curcumin. Food Res Int. (2016) 84:113-9. doi: 10.1016/j.foodres.2016.03.031

45. Aluani D, Tzankova V, Kondeva-Burdina M, Yordanov Y, Nikolova E, Odzhakov F, et al. Evaluation of biocompatibility and antioxidant efficiency of chitosan-alginate nanoparticles loaded with quercetin. Int J Biol Macromol. (2017) 103:771-82. doi: 10.1016/j.ijbiomac.2017. 05.062

46. Athinarayanan J, Periasamy VS, Alhazmi M, Alatiah KA, Alshatwi AA. Synthesis of biogenic silica nanoparticles from rice husks for biomedical applications. Ceram Int. (2015) 1:275-81. doi: 10.1016/j.ceramint.2014.08.069

47. Gnanasekar S, Murugaraj J, Dhivyabharathi B, Krishnamoorthy V, Jha PK, Seetharaman P, et al. Antibacterial and cytotoxicity effects of biogenic palladium nanoparticles synthesized using fruit extract of Couroupita guianensis Aubl. J Appl Biomed. (2017) 16:59-65. doi: 10.1016/j.jab.2017.10.001

48. Pandey S, Klerk CDe, Kim J, Kang M, Fosso-Kankeu E. Eco friendly approach for synthesis, characterization and biological activities of milk protein stabilized silver nanoparticles. Polym. (2020) 12:1418. doi: 10.3390/polym 12061418

49. Tan C, Xie J, Zhang X, Cai J, Xia S. Polysaccharide-based nanoparticles by chitosan and gum arabic polyelectrolyte complexation as carriers for curcumin. Food Hydrocoll. (2016) 57:236-45. doi: $10.1016 /$ j.foodhyd.2016.01.021 
50. Mitura KA, Zarzycki PK. Biocompatibility and toxicity of allotropic forms of carbon in food packaging. Role Mater Sci Food Bioeng. (2018) 6:73-107. doi: 10.1016/B978-0-12-811448-3.00003-6

51. Dhull SB, Punia S. Essential fatty acids : introduction. Essent Fat Acids. (2020) 1:1-18. doi: 10.1201/9780429321115-1

52. Dhull SB, Punia S, Sandhu KS. Essential Fatty Acids. Boca Raton, FL: CRC Press (2020). doi: 10.1201/9780429321115

53. Dhull SB, Punia S. Sources : plants, animals and microbial. Essent Fat Acids. (2020) 2:19-56. doi: 10.1201/9780429321115-2

54. McClements DJ, Öztürk B. Utilization of nanotechnology to improve the handling, storage and biocompatibility of bioactive lipids in food applications. Foods. (2021) 10:1-17. doi: 10.3390/foods10020365

55. Kettiger H, Schipanski A, Wick P, Huwyler J. Engineered nanomaterial uptake and tissue distribution: from cell to organism. Int J Nanomedicine. (2013) 8:3255. doi: 10.2147/IJN.S49770

56. Sanoj Rejinold N, Muthunarayanan M, Divyarani VV, Sreerekha PR, Chennazhi KP, Nair SV, et al. Curcumin-loaded biocompatible thermoresponsive polymeric nanoparticles for cancer drug delivery. $J$ Colloid Interface Sci. (2011) 360:39-51. doi: 10.1016/j.jcis.2011.04.006

57. Siegrist S, Cörek E, Detampel P, Sandström J, Wick P, Huwyler J. Preclinical hazard evaluation strategy for nanomedicines. Nanotoxicology. (2019) 13:7399. doi: 10.1080/17435390.2018.1505000

58. Lee JH, Cha KE, Kim MS, Hong HW, Chung DJ, Ryu G, et al. Nanosized polyamidoamine (PAMAM) dendrimer-induced apoptosis mediated by mitochondrial dysfunction. Toxicol Lett. (2009) 190:202-7. doi: 10.1016/j.toxlet.2009.07.018

59. Leroueil PR, Berry SA, Duthie K, Han G, Rotello VM, McNerny DQ, et al. Wide varieties of cationic nanoparticles induce defects in supported lipid bilayers. Nano Lett. (2008) 8:420-4. doi: 10.1021/nl0722929

60. Li X, Wang L, Fan Y, Feng Q, Cui FZ. Biocompatibility and toxicity of nanoparticles and nanotubes. J Nanomater. (2012) 2012:548389. doi: $10.1155 / 2012 / 548389$

61. Irfan S, Khan MA, Nadeem HR, Ranjha MMAN, Shafique B, Khalid U, et al. Nanozymes: new facets in food science and technology. In: FD Mobo, $\mathrm{Z}$ Sakhi, editors, Proceedings of the Tokyo Summit-2 2nd International Conference on Innovative Studies of Contemporary Sciences. Tokyo (2020).

62. Ravichandran R. Nanotechnology applications in food and food processing: innovative green approaches, opportunities and uncertainties for global market. Int J Green Nanotechnol Phys Chem. (2010) 1:72-P96, doi: 10.1080/19430871003684440

63. EFSA. Outcome of the Public Consultation on the Draft Guidance on Risk Assessment of the Application of Nanoscience and Nanotechnologies in the Food and Feed Chain: Part 1, Human and Animal Health. Parma: EFSA Support. Publ. (2018). p. 15.

64. More S, Bampidis V, Benford D, Bragard C, Halldorsson T, Hernández-Jerez A, et al. Guidance on technical requirements for regulated food and feed product applications to establish the presence of small particles including nanoparticles. EFSA J. (2021) 19:6769. doi: 10.2903/j.efsa.2021.6769

65. EFSA. Guidance on Risk Assessment of Nanomaterials to be Applied in the Food and Feed Chain: Human and Animal Health. Available online at: https://www.efsa.europa.eu/en/efsajournal/pub/6768 (accessed November 4, 2021).

66. Kunzmann A, Andersson B, Thurnherr T, Krug H, Scheynius A, Fadeel B. Toxicology of engineered nanomaterials: focus on biocompatibility, biodistribution and biodegradation. Biochim Biophys Acta Gen Subj. (2011) 7:361-73. doi: 10.1016/j.bbagen.2010.04.007

67. Scott $N$, Chen $H$. Overview nanoscale science and engineering for agriculture and food systems. Indus Biotechnol. (2012) 8:1549. doi: 10.1089/ind.2012.1549

68. Beg S, Barkat MA, Ahmad FJ. Nanophytomedicine. Singapore: Springer Singapore (2020).

69. Mohi-ud-din R, Mir RH, Pottoo FH, Sawhney G, Masoodi MH, Bhat ZA. Nanophytomedicine ethical issues, regulatory aspects, and challenges. Nanophytomedicine. (2020) 10:173-92. doi: 10.1007/978-981-15-4909-0_10

70. Dwivedi S, Saquib Q, Al-Khedhairy AA, Musarrat J. Understanding the role of nanomaterials in agriculture. Microb Inoculants Sustain Agric Product. (2016) 2:271-88. doi: 10.1007/978-81-322-2644-4_17
71. Bala K, Dhull SB, Punia S, Barmanray A. Essential oil nanoemulsions : as natural antimicrobial agents. Nanotechnol Approach Food Microbiol. (2020) 9:227-47. doi: 10.1201/9780429342776-9

72. Dhull SB, Anju M, Punia S, Kaushik R, Chawla P. Application of gum arabic in nanoemulsion for safe conveyance of bioactive components. Nanobiotechnol Bioformulat. (2019) 3:85-98. doi: 10.1007/978-3-030-17061-5_3

73. Wang H, Du L-J, Song Z-M, Chen XX. Progress in the characterization and safety evaluation of engineered inorganic nanomaterials in food. Nanomedicine. (2013) 8:2007-26. doi: 10.2217/nnm.13.176

74. Piñón-Balderrama CI, Leyva-Porras C, Terán-Figueroa Y, Espinosa-Solís V, Álvarez-Salas C, Saavedra-Leos MZ. Encapsulation of active ingredients in food industry by spray-drying and nano spray-drying technologies. Process. (2020) 8:889. doi: 10.3390/pr8080889

75. Ahmad M, Mudgil P, Gani A, Hamed F, Masoodi FA, Maqsood S. Nanoencapsulation of catechin in starch nanoparticles: characterization, release behavior and bioactivity retention during simulated in-vitro digestion. Food Chem. (2019) 270:95-104. doi: 10.1016/j.foodchem.2018.07.024

76. Acosta E. Bioavailability of nanoparticles in nutrient and nutraceutical delivery. Curr Opin Colloid Interface Sci. (2009) 14:3-15. doi: 10.1016/j.cocis.2008.01.002

77. Ratnam DV, Ankola DD, Bhardwaj V, Sahana DK, Kumar MNVR. Role of antioxidants in prophylaxis and therapy: a pharmaceutical perspective. $J$ Control Release. (2006) 113:189-207. doi: 10.1016/j.jconrel.2006.04.015

78. Khosravi-Darani K, Pardakhty A, Honarpisheh H, Rao VSNM, Mozafari MR. The role of high-resolution imaging in the evaluation of nanosystems for bioactive encapsulation and targeted nanotherapy. Micron. (2007) 38:804-18. doi: 10.1016/j.micron.2007.06.009

79. Khare S, Williams K, Gokulan K. Nanotechnology. Encycl Food Microbiol. (2014) 7:893-900. doi: 10.1016/B978-0-12-384730-0.00406-7

80. Ranzoni A, Cooper MA. The growing influence of nanotechnology in our lives. Micro Nanotechnol Vaccine Dev. (2017) 4:1-20. doi: 10.1016/B978-0-323-39981-4.00001-4

81. Sung SY, Sin LT, Tee TT, Bee ST, Rahmat AR, Rahman WA, et al. Antimicrobial agents for food packaging applications. Trends Food Sci Technol. (2013) 33:110-23. doi: 10.1016/j.tifs.2013.08.001

82. Pranoto Y, Rakshit SK, Salokhe VM. Enhancing antimicrobial activity of chitosan films by incorporating garlic oil, potassium sorbate and nisin. $L W T$ Food Sci Technol. (2005) 38:859-65. doi: 10.1016/j.lwt.2004.09.014

83. Han J, Castell-Perez ME, Moreira RG. The influence of electron beam irradiation of antimicrobial-coated LDPE/polyamide films on antimicrobial activity and film properties. LWT Food Sci Technol. (2007) 40:1545-54. doi: 10.1016/j.lwt.2006.11.012

84. Nadarajah D, Han JH, Holley RA. Inactivation of Escherichia coli O157:H7 in packaged ground beef by allyl isothiocyanate. Int J Food Microbiol. (2005) 99:269-79. doi: 10.1016/j.ijfoodmicro.2004.08.019

85. Chibane LB, Degraeve P, Ferhout H, Bouajila J, Oulahal N. Plant antimicrobial polyphenols as potential natural food preservatives. J Sci Food Agric. (2019) 99:1457-74. doi: 10.1002/jsfa.9357

86. Engel E, Michiardi A, Navarro M, Lacroix D, Planell JA. Nanotechnology in regenerative medicine: the materials side. Trends Biotechnol. (2008) 26:3947. doi: 10.1016/j.tibtech.2007.10.005

87. Gilmartin N, O'Kennedy R. Nanobiotechnologies for the detection and reduction of pathogens. Enzyme Microb Technol. (2012) 50:87-95. doi: 10.1016/j.enzmictec.2011.11.005

88. Kowsalya E, Mosa Christas K, Balashanmugam P, Tamil Selvi A, Jaquline Chinna Rani I. Biocompatible silver nanoparticles/poly(vinyl alcohol) electrospun nanofibers for potential antimicrobial food packaging applications. Food Packag Shelf Life. (2019) 21:100379. doi: 10.1016/j.fpsl.2019.100379

89. Ghosh C, Bera D, Roy L. Role of nanomaterials in food preservation. Nanotechnol Life Sci. (2019) 10:181-211. doi: 10.1007/978-3-030-16534-5_10

90. Joye IJ, Corradini MG, Duizer LM, Bohrer BM, LaPointe G, Farber JM, et al. comprehensive perspective of food nanomaterials. Adv Food Nutr Res. (2019) 88:1-45. doi: 10.1016/bs.afnr.2019.01.001

91. Li L, Wang C, Luo J, Guo Q, Liu K, Liu K, et al. Fe3+-functionalized carbon quantum dots: a facile preparation strategy and detection for 
ascorbic acid in rat brain microdialysates. Talanta. (2015) 144:1301-7. doi: $10.1016 /$ j.talanta.2015.08.003

92. El-Boubbou K, Gruden C, Huang X. Magnetic Glyco-nanoparticles: a unique tool for rapid pathogen detection, decontamination, and strain differentiation. J Am Chem Soc. (2007) 129:13392-3. doi: 10.1021/ja076086e

93. Miguel Aguilera J. The food matrix: implications in processing, nutrition and health. J Crit Rev Food Sci Nut. (2018) 59:3612-29. doi: 10.1080/10408398.2018.1502743

94. Pan M, Yin Z, Liu K, Du X, Liu H, Wang S. Carbon-based nanomaterials in sensors for food safety. Nanomater. (2019) 9:1330. doi: 10.3390/nano9091330

95. Yang T, Duncan TV. Challenges and potential solutions for nanosensors intended for use with foods. Nat Nanotechnol. (2021) 16:251-65. doi: 10.1038/s41565-021-00867-7

96. Lv M, Liu Y, Geng J, Kou X, Xin Z, Yang D. Engineering nanomaterials-based biosensors for food safety detection. Biosens Bioelectron. (2018) 106:122-8. doi: 10.1016/j.bios.2018.01.049

97. Pereda M, Marcovich NE, Ansorena MR. Nanotechnology in food packaging applications: barrier materials, antimicrobial agents, sensors, and safety assessment. Handb Ecomater. (2019) 3:2035-56. doi: 10.1007/978-3-319-68255-6_30

98. Al-Othman MR, Abd El-Aziz ARM, Mahmoud MA, Eifan SA, ElShikh MS, Majrashi M. Application of silver nanoparticles as antifungal and antiaflatoxin $\mathrm{B}_{1}$ produced by Aspergillus flavus. Dig J Nanomater Biostructures. (2014) 9:151-7.

99. Sharma C, Dhiman R, Rokana N, Panwar H. Nanotechnology: an untapped resource for food packaging. Front Microbiol. (2017) 2017:1735. doi: $10.3389 /$ fmicb.2017.01735

100. Bumbudsanpharoke N, Ko S. Nano-food packaging: an overview of market, migration research, and safety regulations. J Food Sci. (2015) 80:R910-23. doi: $10.1111 / 1750-3841.12861$

101. Lavoine N, Desloges I, Bras J. Microfibrillated cellulose coatings as new release systems for active packaging. Carbohydr Polym. (2014) 103:528-37. doi: 10.1016/j.carbpol.2013.12.035

102. Bharimalla AK, Patil PG, Mukherjee S, Yadav V, Prasad V. Nanocellulosepolymer composites: novel materials for food packaging applications. Polym Agri-Food Appl. (2019) 27:553-99. doi: 10.1007/978-3-030-19416-1_27

103. Metak AM. Effects of Nanocomposite Based Nano-Silver and Nano-Titanium Dioxideon Food Packaging Materials. Available online at: http://www.ijastnet. com/journals/Vol_5_No_2_April_2015/4.pdf (accessed November 4, 2021).

104. Metak MA, Ajlaal TT. Investigation on Polymer Based Nano-Silver as Food Packaging Materials. Available online at: https://publications.waset.org/ 9996608/investigation-on- polymer-based-nano-silver-as-food-packagingmaterials (accessed November 4, 2021).

105. Wei H, Yanjun YU Li N, Libing W. Application and safety assessment for nano-composite materials in food packaging. Chinese Sci Bull. (2011) 56:1216-25. doi: 10.1007/s11434-010-4326-6

106. Marin-Bustamante MQ, Chanona-Pérez JJ, G?emes-Vera N, MendozaPérez JA, Reséndiz-Mora CA, Cásarez-Santiago RG, et al. Nanomaterials, polymers, and smart packaging for food materials. Nanotechnol Life Sci. (2019) 7:199-216. doi: 10.1007/978-3-030-16379-2_7

107. Egodage D, Jayalath H, Samarasekara A, Amarasinghe D, Madushani S, Senerath S. Novel antimicrobial nano coated polypropylene based materials for food packaging systems. In: 2017 Moratuwa Engineering Research Conference (MERCon). Moratuwa: IEEE (2017). p. 88-92. doi: 10.1109/MERCon.2017.7980462

108. Ranjha MM, Shafique B, Batool M, Kowalczewski P£, Shehzad Q, Usman $\mathrm{M}$, et al. Nutritional and health potential of probiotics: a review. Appl Sci. (2021) 11 .

109. Otoni CG, Azeredo HMC, Mattos BD, Beaumont M, Correa DS, Rojas OJ. The food-materials nexus: next generation bioplastics and advanced materials from agri-food residues. Adv Mater. (2021) 33:2102520. doi: 10.1002/adma.202102520

110. Azeredo HMC, Otoni CG, Corrêa DS, Assis OBG, de Moura MR, Mattoso LHC. Nanostructured antimicrobials in food packaging-recent advances. Biotechnol J. (2019) 14:68. doi: 10.1002/biot.201900068

111. Sorrentino A, Gorrasi G, Vittoria V. Potential perspectives of bionanocomposites for food packaging applications. Trends Food Sci Technol. (2007) 18:84-95. doi: 10.1016/j.tifs.2006.09.004
112. Youssef AM, El-Sayed SM. Bionanocomposites materials for food packaging applications: concepts and future outlook. Carbohydr Polym. (2018) 193:1927. doi: 10.1016/j.carbpol.2018.03.088

113. Pateiro M, Gómez B, Munekata PES, Barba FJ, Putnik P, Kovačević DB, et al. Nanoencapsulation of promising bioactive compounds to improve their absorption, stability. functionality and the appearance of the final food products. Molecules. (2021) 26:1547. doi: 10.3390/molecules 26061547

114. Akhavan S, Assadpour E, Katouzian I, Jafari SM. Lipid nano scale cargos for the protection and delivery of food bioactive ingredients and nutraceuticals. Trends Food Sci Technol. (2018) 74:132-46. doi: 10.1016/j.tifs.2018.02.001

115. Bilia AR, Isacchi B, Righeschi C, Guccione C, Bergonzi MC, Bilia AR, et al. Flavonoids loaded in nanocarriers: an opportunity to increase oral bioavailability and bioefficacy. Food Nutr Sci. (2014) 5:1212-327. doi: $10.4236 /$ fns.2014.513132

116. Hafner A, Lovrić J, Lakoš GP, Pepić I. Nanotherapeutics in the EU: an overview on current state and future directions. Int J Nanomed. (2014) 9:1005-23. doi: 10.2147/IJN.S55359

117. US EPA. Documentation for Greenhouse Gas Emission and Energy Factors Used in the Waste Reduction Model (WARM) Containers, Packaging, and Non-Durable Good Materials Chapters. Washington, DC: U.S. Environmental Protection Agency (2015).

118. FDA. Nanotechnology Fact Sheet. Food and Drug administartion (2021). Available online at: https://www.fda.gov/science-research/nanotechnologyprograms-fda/nanotechnology-fact-sheet (accessed November 5, 2021).

119. ECHA. Regulation - ECHA. Available online at: https://euon.echa.europa.eu/ regulation (accessed November 5, 2021).

120. Espitia PJP, Otoni CG. Nanotechnology and edible films for food packaging applications. Bio-based Mater. Food Packag Green Sustain Adv Packag Mater. (2018) 6:125-45. doi: 10.1007/978-981-13-1909-9_6

121. Park JH, Gu L, Von Maltzahn G, Ruoslahti E, Bhatia SN, Sailor MJ. Biodegradable luminescent porous silicon nanoparticles for in vivo applications. Nat Mater. (2009) 8:331-6. doi: 10.1038/nmat2398

122. De Angelis F, Pujia A, Falcone C, Iaccino E, Palmieri C, Liberale C, et al. Water soluble nanoporous nanoparticle for in vivo targeted drug delivery and controlled release in B cells tumor context. Nanoscale. (2010) 2:2230-6. doi: 10.1039/c0nr00161a

123. Durán N, Marcato PD. Nanobiotechnology perspectives. Role of nanotechnology in the food industry: a review. Int J Food Sci Technol. (2013) 48:1127-34. doi: 10.1111/ijfs.12027

124. Joubert IA, Geppert M, Ess S, Nestelbacher R, Gadermaier G, Duschl $\mathrm{A}$, et al. Public perception and knowledge on nanotechnology: a study based on a citizen science approach. NanoImpact. (2020) 17:100201. doi: 10.1016/j.impact.2019.100201

125. Boholm $\AA$, Larsson S. What is the problem? A literature review on challenges facing the communication of nanotechnology to the public. J Nanoparticle Res. (2019) 21:1-21. doi: 10.1007/s11051-019-4524-3

Author Disclaimer: The contents are solely the responsibility of the authors and do not necessarily represent the official views of NIFA.

Conflict of Interest: The authors declare that the research was conducted in the absence of any commercial or financial relationships that could be construed as a potential conflict of interest.

Publisher's Note: All claims expressed in this article are solely those of the authors and do not necessarily represent those of their affiliated organizations, or those of the publisher, the editors and the reviewers. Any product that may be evaluated in this article, or claim that may be made by its manufacturer, is not guaranteed or endorsed by the publisher.

Copyright $\odot 2022$ Ranjha, Shafique, Rehman, Mehmood, Ali, Zahra, Roobab, Singh, Ibrahim and Siddiqui. This is an open-access article distributed under the terms of the Creative Commons Attribution License (CC BY). The use, distribution or reproduction in other forums is permitted, provided the original author(s) and the copyright owner(s) are credited and that the original publication in this journal is cited, in accordance with accepted academic practice. No use, distribution or reproduction is permitted which does not comply with these terms. 